\title{
Chemical Mutagenesis and Cytogenetic Chromosomal Abnormalities in a Population Living in the Aral Sea region
}

\author{
Zhanbol Sabirov $^{1,2 \star}$, Zulkiya Namazbaeva ${ }^{1}$, Sharbanu Battakova ${ }^{1}$, Maral Otarbayeva $^{1}$, Manara Mukasheva ${ }^{2}$ and \\ Aliya Yeshmagambetova ${ }^{2}$ \\ ${ }^{1}$ The scientific-research sanitary-hygienic laboratory of the Institute of Public Health and Professional Health, NC JSC "MUK", \\ Karagandy, Kazakhstan; ${ }^{2}$ Department of Physiology, NC JSC Karaganda University named after Academician E.A. Buketova, \\ Karagandy, Kazakhstan
}

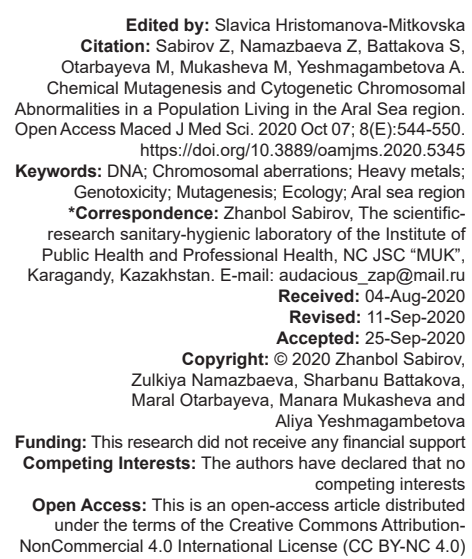

Edited by: Slavica Hristomanova-Mitkovska Citation: Sabirov Z, Namazbaeva Z, Battakova S, Citation: Sabirov Z, Namazbaeva Z, Battakova S,
Otarbayeva M, Mukasheva M, Yeshmagambetova A. Chemical Mutagenesis and Cytogenetic Chromosomal Abnormalities in a Population Living in the Aral Sea region. Abnormalities in a Population Living in the Aral Sea region.
Open Access Maced J Med Sci. 2020 Oct 07; 8(E):544-550. https://doi.org/10.3889/oamjms.2020.5345
Keywords: DNA. Chromosomal aberrations; Heavy metals; Keywords: DNA; Chromosomal aberrations; Heavy metals; Genotoxicity; Mutagenesis; Ecology; Aral sea region
*Correspondence: Zhanbol Sabirov, The scientificresearch sanitary-hygienic laboratory of the Institute of Public Health and Professional Health, NC JSC "MUK" Karagandy, Kazakhstan. E-mail: audacious_zap@mail.ru Received: 04-Aug-2020 Accepted: $25-$ Sep-2020 Accepted: $25-$ Sep-2020
Copyright: $\odot 2020$ Zhanbol Sabirov, Zulkiya Namazbaeva, Sharbanu Battakova Maral Otarbayeva, Manara Mukasheva and Aliya Yeshmagambetova Funding: This research did not receive any financial support Competing Interests: The authors have declared that no Open Access: This is an open-access article distributs under the terms of the Creative Commons AttributionNonCommercial 4.0 International License (CC BY-NC 4.0)

\begin{abstract}
AIM: The article presents the results of a study of chromosomal mutations in residents living in the Aral Sea disaster zone, using the example of the city of Aralsk.

METHODS: The article identifies the level of chromosomal aberrations (CA) in the surveyed population and identifies the leading type of aberrations in this region.

RESULTS: Researches have shown that the main types of structural changes were chromatid breaks and single fragments of chromosomes. The results showed that in the study population, the microelement status indicates an imbalance of microelements. A correlation analysis showed a relationship between the nickel content in the blood and the increase in CAs. Furthermore, researches show a hypothesis about the pathogenesis mechanism of the formation of CAs.

CONCLUSION: Thus, the article provides information on chromosomal mutations during chemical mutagenesis.
\end{abstract}

\section{Introduction}

Environmental pollution and the consequences of its impact on public health are one of the most pressing issues for the world community. In many ecologically unfavorable regions, a difficult situation persists for a long time: air pollution, soil salinization, pollution of drinking water, which negatively affects the health of the population at various levels (molecular, cellular, organ, and systemic). Environmental pollution has a negative impact on the health status of the population [1], [2], [3], [4], [5].

The negative impact of adverse environmental factors on the health of the population has become special significance both for the whole world and for Kazakhstan.

Aral Sea shallowing and partial drying affects the interests of all countries in Central Asia and is a matter of concern on the part of the world community. This situation has been noted as an Aral Sea disaster and has led to significant economic damage and to harmful effects on human habitat.
Various researches show that pollution of the area near the Aral Sea by heavy metals affects the development of diseases of various organs and systems [6], [7], [8], [9], [10], [11], [12].

This environmental situation has a negative effect on public health, including genotoxic ones, and can manifest itself as chromosomal abnormalities such as an increase in size, a change in shape, and chromosomal aberration (CA) [13], [14].

One of the problems of hygienic significance is the problem of the genetic consequences of their effects, which are manifested at the chromosomal level and underlying the malignant transformation of cells, the increase in cases of the disease, and decrease in the body's resistance to environmental factors [15], [16].

Numerous epidemiological, laboratory, and clinical observations indicate for the presence of causeeffect relationships between environmental pollution and damage to the genetic material of the human body. These examinations were carried out both in harmful industrial conditions and in living areas, where the atmosphere, water, and soil were contaminated with mutagens [17], [18]. Assessment of the effects of mutagens on humans 
in real conditions (with prolonged exposure of mutagens) is carried out mainly by cytogenetic examination of people exposed to the harmful factors.

Aralsk city of the Kyzylorda region (Population - 33,141 people) located in Southern Kazakhstan, in the zone of ecological disaster at a distance of $17 \mathrm{~km}$ from the Aral Sea [19]. In the south of the city is the dried-up Gulf of the Aral Sea - Bolshoy Saryshyganak. The climate is continental, arid, with large fluctuations in seasonal and daily temperatures.

The studies conducted by the "Scientific and Practical Center for Sanitary and Epidemiological Expertise and Monitoring" showed a high level of chemical load on the population in the conditions of the city of Aralsk [20]. The Aralsk ambient air is polluted with salts of heavy metals (nickel, manganese, lead, cuprum, zinc, iron, and silicon) that exceed the permissible level [21], [22]. In a control area - Atasu city, there is no excess of the above pollutants detected [23].

The aim of cytogenetic researches is to estimate the frequency and qualitative spectrum of chromosomal deviations in peripheral blood lymphocytes of people in reproductive age living in the territory of the Aral Sea ecological disaster zone.

\section{Materials and Methods}

\section{Research design}

Prospective medical case-control study was conducted in Aralsk city (46'48"00" N 61'40"00" E) and in Atasu city (48'41"00" N 71'39"00" E), Kazakhstan.

\section{Conditions and sampling technique}

The level of CAs and the level of microelements in the blood were considered as the main evaluated result.

We analyzed 7465 metaphase plates in 40 healthy people of reproductive age (18-45 years old) in the main group of examined persons who have been living in the ecological disaster zone (Aralsk) since they were born, which were not affected by harmful factors at the workplace.

For comparison purposes, 7020 metaphases were analyzed in 40 individuals living in the city of Atasu (control group). People living in Atasu formed a control group as they lived far from the disaster zone, but the climatic, geographical, and socioeconomic conditions were identical to compared groups.

All subject patients were divided into two groups based on matching parameters such as gender, age, duration of stay, social status, education, profession, and living conditions. The difference between the groups was in living in different ecological regions.
Genotoxic effects were studied using a modified method of peripheral blood lymphocytes cultivation by Hungerford, with the purpose of accounting frequency and types of CAs [24], [25], [26]. The main stages of preparation of chromosome preparations are venous blood sampling, lymphocyte culture, mitosis arrest at the metaphase stage, hypotonization of metaphase lymphocytes, fixation of chromosome sets on a glass slide, and chromosome coloring [26].

For each examined, at least 150 metaphase plates were analyzed. The frequency of CAs was calculated by the formula:

$$
\mathrm{CA}=(\mathrm{a} / \mathrm{b})^{*} 100 \%
$$

Where: $\mathrm{a}$ - is the number of CAs;

$\mathrm{b}$ - is the number of metaphases.

The main purpose of the methods for processing cell cultures and chromosome preparations is the obtaining a sufficient number of metaphase plates with chromosome spread, which makes possible to assess the size, ratio of chromosome shoulder lengths, the presence of secondary constrictions, satellites, and other morphological signs of each karyotype chromosome.

The level of the trace elements in blood: (i.e., copper [Cu], zinc [Zn], cadmium [Cd], mercury [Hg], plumbum [Pb], arsenic [As], chromium [Cr], selenium [Se], manganese [Mn], iron [Fe], nickel [Ni], and iodine [I]) was carried out with MGA-915 atomic absorption spectrometer (Lumeks, Russia).

\section{Inclusion criteria}

Eighty people are without acute gastrological, bronchial obstructive, hemorrhagic, neurological and splenomegaly syndromes, infectious and severe somatic diseases, acute inflammatory processes, mental disorders, and severe physical illnesses. Persons from these groups have been living in their cities since they were born; they were not affected by harmful factors at the workplace. The survey sample included persons of reproductive age from 18 to 45 years.

\section{Discontinuation criteria}

Patients with gastrological, bronchial
obstructive, hemorrhagic, neurological and splenomegaly syndromes, infectious and severe somatic diseases, acute inflammatory processes, mental disorders, persons under 18 years old and over 46 years old, working in harmful working environment were excluded from the study.

\section{Statistical analysis}

Data analysis was carried out with a Statistica 10 software package (StatSoft, USA). Processing operations have included the calculation of arithmetic 
mean values (M), standard errors of arithmetic mean (m), confidence intervals, and standard deviation for variables with normal distributions. The latter was verified by the Shapiro-Wilk test and by the KolmogorovSmirnov test. Differences between the groups with normal distribution were found by means of parametric statistical methods and Student's t-test for two unrelated groups. Linear dependence was determined by means of the Pearson correlation coefficient (PCC) for indicators with a normal distribution.

\section{Results}

The identified CAs were divided into two main groups: Chromosome type and chromatid type. The total frequency of aberrations in the surveyed population amounted to 126 cases and was at $1.167 \pm 0.149 \%$, which is $40 \%$ higher than that in the control group of $1.011 \pm 0.119 \%$. The mean values of aberrations of the chromatid among respondents living in the area of ecological disaster zone were at $1.205 \pm 0.126 \%$. The frequency of chromatid-type aberrations (1.205 \pm $0.126 \%$ ) also exceeded the corresponding values in the control group $(0.655 \pm 0.096 \%) 45 \%$. There were no significant differences between the aberrations of chromosomal type (Figure 1).

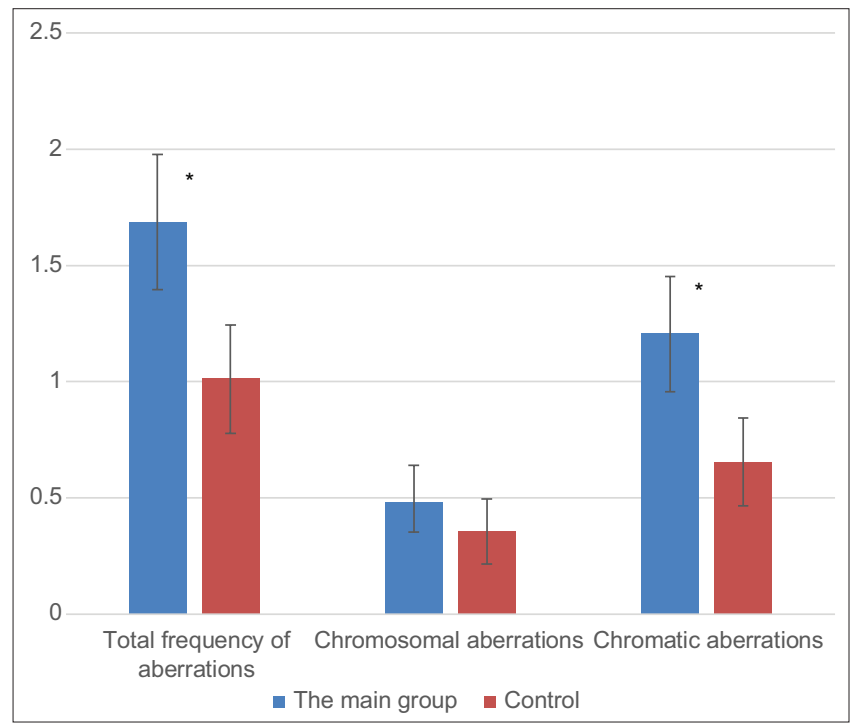

Figure 1: Frequency and types of chromosomal aberrations in the examined individuals living in the area of the Aral Sea ecological disaster zone ( $M \pm m \%$; 95\% confidence intervals). The mark ${ }^{*}$ denotes a significant difference in relation to control numbers by Student's t-test $p<0.05$. Unit of measurement for all values is \%

Analysis of obtained data has shown that the identified chromatid type of aberrations was represented by single fragments, whose share in the total number of aberrations was $59.52 \%$ (75 cases), chromatid breaks of $7.14 \%$ (10 cases), and deletions of $4.76 \%$ (6 cases). Cytogenetic disorders in the control group, mainly represented by the same types of CAs, as in the main group: Single fragments of 49\% (35 cases), chromatid breaks of $9.8 \%$ (7 cases), deletions of $5 \%$ (4 cases).

Chromosome type aberrations were represented by paired fragments, whose contribution to the total number of aberrations was $25.39 \%$ (32 cases), breaks on the centromere of $1.58 \%$ (2 cases), and translocations - is $1.58 \%$ ( 2 cases). In the control group of the chromosome type, there are also paired fragments of $28.16 \%$ (20 cases) of the total number of CAs, center breaks $-5.63 \%$ (4 cases), and interchromosomal translocations $-1.41 \%$ (1 case); ring chromosomes were not found (Table 1).

Table 1: Types of CAs in the examined individuals living in the area of the Aral Sea ecological disaster zone (M $\pm \mathrm{m} \%$; $95 \% \mathrm{Cl}$ )

\begin{tabular}{|c|c|c|c|}
\hline \multirow[t]{2}{*}{ Indicators } & \multicolumn{2}{|c|}{ The studied group } & \multirow[t]{2}{*}{$\mathrm{p}$} \\
\hline & Control & The main group & \\
\hline \multicolumn{4}{|l|}{ Aberrations of chromosomal type } \\
\hline Paired fragments & $\begin{array}{c}0.285 \pm 0.063 \\
(0.160-0.409)\end{array}$ & $\begin{array}{c}0.428 \pm 0.075 \\
(0.280-0.576)\end{array}$ & - \\
\hline Breaks on the centromere & $\begin{array}{c}0.057 \pm 0.028 \\
(0.001-0.112)\end{array}$ & $\begin{array}{c}0.027 \pm 0.018 \\
(0.009-0.045)\end{array}$ & - \\
\hline Translocation & $\begin{array}{c}0.014 \pm 0.013 \\
(0.001-0.027)\end{array}$ & $\begin{array}{c}0.013 \pm 0.012 \\
(0.001-0.025)\end{array}$ & - \\
\hline Acentric fragment & - & $\begin{array}{c}0.013 \pm 0.012 \\
(0.001-0.025)\end{array}$ & - \\
\hline Total & $\begin{array}{l}0.356 \pm 0.071 \\
(0.216-0.495)\end{array}$ & $\begin{array}{l}0.482 \pm 0.080 \\
(0.325-0.639)\end{array}$ & - \\
\hline \multicolumn{4}{|l|}{ Aberrations chromatid type } \\
\hline Chromatid breaks & $\begin{array}{l}0.099 \pm 0.037 \\
(0.025-0.173)\end{array}$ & $\begin{array}{l}0.147 \pm 0.044 \\
(0.060-0.234)\end{array}$ & - \\
\hline Single fragments & $\begin{array}{l}0.498 \pm 0.084 \\
(0.333-0.663)\end{array}$ & $\begin{array}{c}0.991 \pm 0.114 \\
(0.766-1.215)\end{array}$ & 0.0006 \\
\hline Deletions & $\begin{array}{l}0.057 \pm 0.028 \\
(0.001-0.112)\end{array}$ & $\begin{array}{l}0.067 \pm 0.029 \\
(0.008-0.125)\end{array}$ & - \\
\hline Total & $\begin{array}{l}0.655 \pm 0.096 \\
(0.466-0.844)\end{array}$ & $\begin{array}{l}1.205 \pm 0.126 \\
(0.957-1.453)\end{array}$ & 0.0005 \\
\hline
\end{tabular}
relation to control group by Student's t-test. CA: Chromosomal aberration.

The research on chromosomal and chromatid types of aberrations in peripheral blood lymphocytes of patients living in the area of The Aral Sea region has shown a significant prevalence of chromatid aberrations over chromosomal, which indicates on the chemical mutagenesis. Thus, the total number of chromosomal and chromatid aberrations of people living in the ecological disaster zone was divided as follows: $71 \%$ of chromatid type of aberrations and $29 \%$ of chromosomal type. Analyzing obtained data on the types of CAs may be noted that the level of chromatid type aberrations $42 \%$ was higher than the aberrations of chromosomal type (Figure 2). As we know from the literature, the manifestations of chromatid-type aberrations are typical for chemical mutagenesis [27], [28], [29]. The total number of aberrations for the control group was $65 \%$ for chromatid type and $35 \%$ for chromosomal. Many authors support the view that chromatid-type aberrations are formed as a result of exposure to mutagens and damage to the DNA molecule in the synthetic stage [30], [31], [32].

CAs during chemical mutagenesis often occur in the $S$ phase, even when exposed to a factor at any stage of the cell cycle. Consequently, DNA fragments detached from the whole molecule will condense into single fragments, and not into an integral chromosome (Figure 3). 


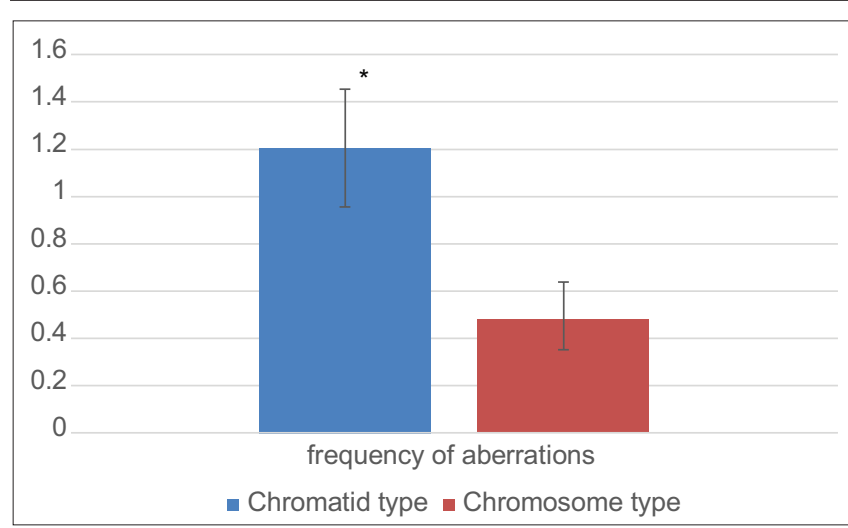

Figure 2: Comparison of types of chromosomal aberrations in the examined individuals living in the area of the Aral Sea ecological disaster zone ( $M \pm m \%$; 95\% confidence intervals). The mark *denotes a significant difference in relation to control numbers by Student's t-test $p<0.05$. Unit of measurement for all values is $\%$

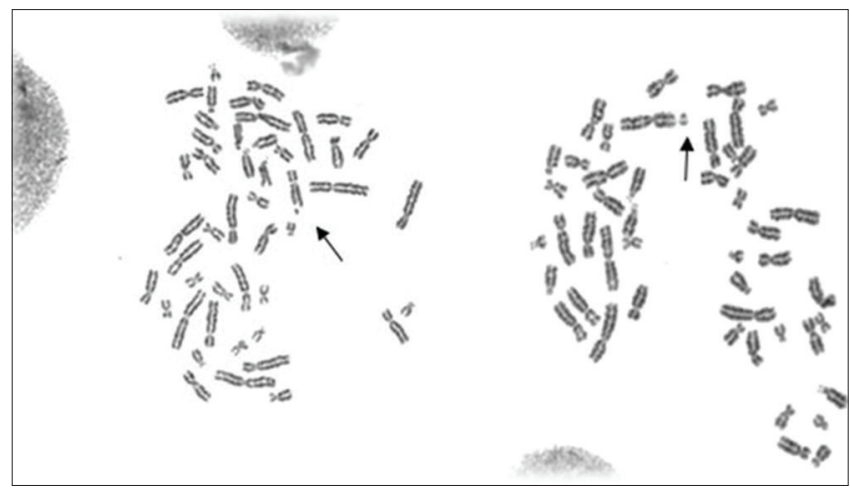

Figure 3: Chromosomal aberrations in peripheral blood lymphocytes of persons living in the area of the Aral Sea ecological disaster zone (chromatid type of aberrations on the left and chromosomal type of aberrations on the right)

The chromatid type of aberrations indicates the predominantly chemical nature of genotoxic agents, although there are exceptions for the general hypothesis, according to which the entire chromosome changes during breaks in the pre-synthetic stage and double aberrations are observed; during breaks at the post-synthetic stage, only one chromatid changes, and single aberrations are observed [32], [33], [34], [35].

Assessing the effect of genotoxic of chemical agents (include heavy metals) on the chromosomal structure was performed correlation analysis between the level of CAs and the content of microelements in the blood.

Obtained results indicate significant chromosomal mutations in examined subjects during adaptation to high chemical load. Blood test for microelements content of people living in the disaster zone has shown that concentration of heavy metals in the blood such as plumbum, nickel, and copper, which have a toxic effect, exceeded control indicators for $98 \%$, $97 \%$, and $41 \%$, respectively.

Continuous chemical load also has a significant effect on the level of essential trace elements in the body of people living in the Aral Sea region. There is a decrease in such important trace elements such as selenium for $38 \%$, zinc for $40 \%$, and iodine $-30 \%$ in comparison with the control group (Table 2).

The conducted analysis has shown a correlation relationship between CA showings and the content of microelements in the blood. Correlation analysis showed a dependence on the total level of chromosome aberration from the level of nickel in the blood (PCC $=0.61)$. Based on the results of regression, a linear prognostic dependence model of total level of chromosome aberration on the nickel level in blood: $y$ (total level of chromosome aberration) $=0.53+0.54{ }^{*} \times$ (regression coefficient is $R=0.61$, determination coefficient $-\mathrm{R} 2=0.36$, Fisher's coefficient $-F=41.05, p<0.01$ ) was developed. Trace element analysis showed that the nickel level in the main group is higher than in the control group in $49.5 \%$. The correlation between the general levels of CAs and the level of nickel in the blood consists of an increase in chromatid type aberrations (PCC $=0.56, p<0.01$ ), and precisely because of the increase in the number of single fragments $(\mathrm{PCC}=0.50, \mathrm{p}<0.05)$.

Furthermore, there was revealed a correlation of aberrations of chromosomal type with cadmium (PCC $=0.29, p<0.05)$; the correlation between the copper content in the blood and single fragments was revealed ( $\mathrm{PCC}=0.30, p<0.05)$. A statistically significant inverse correlation between the zinc level in blood and aberrations of chromatid type was also found $(P C C=0.32, p<0.05)$.

\section{Discussion}

Various studies on the genotoxic activity of chemical agents, such as heavy metals, show

Table 2: Blood trace elements content of examined subjects (main and control groups)

\begin{tabular}{|c|c|c|c|c|}
\hline Indicator & Reference values & Control $\mathrm{M} \pm \mathrm{m}(95 \% \mathrm{Cl})$ & The main group $\mathrm{M} \pm \mathrm{m}(95 \% \mathrm{Cl})$ & $\mathrm{p}$ \\
\hline Copper & $800-1300 \mu \mathrm{g} / \mathrm{l}$ & $966.33 \pm 23.21(919.35-1013.31)$ & $1366.59 \pm 35.65(1294.05-1439.14)$ & 0.01 \\
\hline Zinc & $4000-8600 \mu \mathrm{g} / \mathrm{l}$ & $5859.15 \pm 183.45(5250.13-5822.88)$ & $3516.93 \pm 89.93(3333.93-3699.93)$ & 0.01 \\
\hline Plumbum & Under $25 \mu \mathrm{g} / \mathrm{dl}$ & $2.38 \pm 0.34(1.69-3.07)$ & $4.72 \pm 0.39(3.92-5.52)$ & 0.01 \\
\hline Iron & $309-521 \mathrm{mg} / \mathrm{l}$ & $382.55 \pm 11.11(360.07-405.03)$ & $354.31 \pm 7.46(339.16-369.49)$ & 0.04 \\
\hline Cadmium & $0.3-0.9 \mu \mathrm{g} / \mathrm{dl}$ & $0.38 \pm 0.02(0.53-0.65)$ & $0.57 \pm 0.03(0.49-0.64)$ & - \\
\hline Selenium & $58-234 \mu \mathrm{g} / \mathrm{dl}$ & $85.62 \pm 5.17(75.15-96.08)$ & $52.88 \pm 1.83(49.15-56.61)$ & 0.01 \\
\hline Nickel & $1-50 \mu \mathrm{g} / \mathrm{l}$ & $2.45 \pm 0.21(2.03-2.87)$ & $4.85 \pm 0.36(4.11-5.61)$ & 0.01 \\
\hline Manganese & $1.6-75 \mu \mathrm{g} / \mathrm{l}$ & $3.78 \pm 0.37(3.02-4.54)$ & $4.81 \pm 0.38(4.01-5.59)$ & - \\
\hline lodine & $5-12 \mu \mathrm{g} / \mathrm{l}$ & $7.03 \pm 0.28(6.45-7.60)$ & $4.90 \pm 0.35(4.17-5.63)$ & 0.01 \\
\hline Arsenic & $0.002-3 \mu \mathrm{g} / \mathrm{dl}$ & $1.50 \pm 0.14(1.21-1.79)$ & $0.10 \pm 0.02(0.05-0.15)$ & 0.01 \\
\hline Chromium & $0.7-2.8 \mu \mathrm{g} / \mathrm{l}$ & $1.52 \pm 0.09(1.32-1.72)$ & $1.30 \pm 0.08(1.13-1.47)$ & - \\
\hline
\end{tabular}


that these substances are capable of exhibiting mutagenic properties, often manifesting themselves as CAs [36], [37], [38], [39], [40], [41].

Considering the mechanisms of damage to chromosome structures, we may say that under the influence of various chemical agents, which include heavy metals, damage to the tertiary structure of chromosomes occurs, which leads to partial denaturation of DNA, when binding of divalent heavy metals to DNA, mutations such as transversions and transitions are possible. Hence, they can cause CAs, inducing point mutations, disrupt enzyme interactions, inhibiting individual enzymes.

A DNA molecule has several active centers that coordinate metal ions. First of all, these are oxygen ions of phosphate groups that carry negative charges. Some atoms of nitrogenous bases that enter grooves can also interact with metal ions. The seventh nitrogen atom of guanine is the most favorable position for the binding of positive ligands to DNA bases [38], [42].

The nature of the interaction of metal ions with various binding sites on the DNA molecule is determined by the charge of the ion and the structure of the electron shell of this ion. Ions of alkali $\left(\mathrm{Na}^{+}, \mathrm{Li}^{+}, \mathrm{K}^{+}\right)$and alkalineearth $\left(\mathrm{Mg}^{2+}, \mathrm{Ca}^{2+}, \mathrm{Ba}^{2+}\right)$ metals interact mainly with phosphate groups of DNA. Ions of transition metal $\left(\mathrm{Ni}^{2+}\right.$, $\mathrm{Mn}^{2+}, \mathrm{Zn}^{2+}$, and $\left.\mathrm{Cu}^{2+}\right)$ actively bind to phosphate groups and bases [38].

The fact of the interaction of nickel with nitrogenous DNA bases was revealed by fixing changes in the spectral properties of DNA [38].

The mechanisms of the effect of low concentrations of chemical factors on chromosomal structures have not been sufficiently studied. They can be direct and indirect [32], [38], [39], [43], [44].

Given all the above, there is practically no data about the mechanism of the formation of CAs under the action of heavy metal ions.

We assume that in the presence of some metal ions ( $\mathrm{Ni}, \mathrm{Cd}, \mathrm{Mn})$, the accuracy of DNA synthesis decreases; this is due to the ability of these elements to interact with the first nitrogen atoms through a donoracceptor bond (nitrogen is a donor because it has an unshared electron pair), which can lead to transitions, base loss, and point mutations.

The ions of these metals are able to form an ionic bond with a phosphate group, which leads to a rupture of the phosphodiester bond between the phosphoric acid residue and deoxyribose; as a result, single fragments can form at the metaphase stage.

The pathways for the formation of chromosomal mutations, when exposed to a chemical factor, may be different. In addition to the direct genotoxic effect of chemical factors exerted on DNA, heavy metals also activate antioxidant defense system enzymes, which with prolonged chemical stress, can damage cellular structures by oxidizing the membrane components of the cell.

\section{Conclusion}

To sum up, long-term chemical load in the ecological disaster zone of the Aral Sea causes an increase in CA in population, in particular, in people of fertile age.

Obtained results indicate significant cytogenetic disorders in examined subjects during adaptation to a high chemical load.

The level of CAs in the examined persons living in the ecological disaster zone of the Aral Sea was $1.677 \pm 0.149 \%$ and was in $40 \%$ significantly higher than in the control group $(1.011 \pm 0.119 \%)$.

Research findings recorded a significant increase of nickel by $97 \%$ in comparison with the control group and a decrease in vital essential trace elements (zinc, selenium, and iodine). Zinc level in blood was decreased by $40 \%$ in the main group in comparison with the control group.

The increased level of mutagenic load in the study group relative to the control is due to chemical mutagenesis, which is confirmed by the revealed chromatid-type aberration and correlation analysis.

Correlation and regression analysis determined that the nickel level in blood effects on the total level of chromosome aberration, the zinc level in blood and aberrations of chromatid type were in inverse relationships.

According to correlation analysis, an increase in trace elements (nickel, cadmium, and copper) in the blood can lead to undesirable consequences in the form of chromosomal abnormalities.

One of the mechanisms of the formation of CAs under the influence of a chemical factor may be newly formed atomic bonds between chemical elements and a DNA molecule, as a result of competition for an unshared pair of electrons of donor atoms of a DNA molecule

The current study supports the conclusion that at least in part some of these physiological relationships are potentially heightened in populations living in areas with significant ecological disturbances.

Any changes of trace elements and cytogenetic disorders reflect intoxication under long-term chemical load among the population in the ecological disaster zone of the Aral Sea region. As these changes characterize the toxicodynamic response of the body, they can be used as diagnostic parameters of high sensitivity, specificity, and prognostic significance. 
Thereby, the revealed CAs can be a warning signal about the possible genetic consequences since they disrupt the balance of hereditary factors, they are the cause of a variety of abnormalities in the structure and life of the organism, manifested in the chromosomal abnormalities, diseases and syndromes.

Human heredity and the quality of its living conditions determine both the state of its health and society as a whole.

\section{References}

1. Prss-Ustn A, Wolf J, Corvaln C, Bos R, Neira M. Preventing Disease Through Healthy Environments: A Global Assessment of the Burden of Disease from Environmental Risks. Geneva: World Health Organization; 2016. Available from: https://www.apps.who.int/iris/ bitstream/ handle/10665/204585/9789241565196_eng.pdf;jsessionid=D7 D004ED726D3267C2796D2672738E64? sequence=1. https:// doi.org/10.1016/j.toxlet.2016.07.028

2. World Health Organization. A Global Brief on Vector-borne Diseases. Geneva: World Health Organization; 2014. Available from: https://www.apps.who.int/iris/bitstream/handle/ 10665/111008/WHO_DCO_WHD_2014.1_eng.pdf?sequence=1.

3. Wolf J, Prüss-Ustün A, Cumming $\mathrm{O}$, Bartram J, Bonjour $\mathrm{S}$, Cairncross $\mathrm{S}$, et al. Assessing the impact of drinking water and sanitation on diarrhoeal disease in low-and middle-income settings: Systematic review and meta-regression. Trop Med Int Health. 2014;19(8):928-42. https://doi.org/10.1111/tmi.12331 PMid:24811732

4. Hou L, Wang D, Baccarelli A. Environmental chemicals and microRNAs. Mutat Res. 2011;714(1-2):105-12. https://doi. org/10.1016/j.mrfmmm.2011.05.004

PMid:21609724

5. Tchounwou PB, Yedjou CG, Patlolla AK, Sutton DJ. Heavy metal toxicity and the environment. In: Molecular, Clinical and Environmental Toxicology. Basel: Springer; 2012. p. 133-64. https://doi.org/10.1007/978-3-7643-8340-4_6

6. Sakiev K, Battakova S, Namazbaeva Z, Ibrayeva L, Otarbayeva M, Sabirov Z. Neuropsychological state of the population living in the Aral Sea region (zone of ecological crisis). Int J Occup Environ Health. 2017;23(2):87-93. https:// doi.org/10.1080/10773525.2018.1425655

PMid:29359636

7. Namazbaeva Z, Battakova S, Ibrayeva L, Sabirov Z. Change in metabolic and cognitive state among people of the Aral zone of ecological disaster. Israel J Ecol Evol. 2018;64(1-4):44-55. https://doi.org/10.1163/22244662-20181035

8. Ataniyazova OA, Baumann RA, Liem AK, Mukhopadhyay UA, Vogelaar EF, Boersma ER. Levels of certain metals, organochlorine pesticides and dioxins in cord blood, maternal blood, human milk and some commonly used nutrients in the surroundings of the Aral Sea (Karakalpakstan, republic of Uzbekistan). Acta Paediatr. 2001;90(7):801-8. https://doi. org/10.1111/j.1651-2227.2001.tb02808.x

PMid:11519985

9. Hashizume M, Kunii O, Sasaki S, Shimoda T, Wakai S, Mazhitova Z, et al. Anemia and iron deficiency among schoolchildren in the Aral Sea region, Kazakhstan. J Trop Pediatr. 2003;49(3):172-7. https://doi.org/10.1093/tropej/49.3.172 PMid:12848209
10. Erdinger L, Eckl $P$, Ingel $F$, Khussainova $S$, Utegenova $E$, Mann V, et al. The Aral Sea disaster-human biomonitoring of $\mathrm{Hg}, \mathrm{As}, \mathrm{HCB}, \mathrm{DDE}$, and PCBs in children living in Aralsk and Akchi, Kazakhstan. Int J Hyg Environ Health. 2004;207(6):5417. https://doi.org/10.1078/1438-4639-00325

11. Kaneko K, Chiba M, Hashizume M, Kunii O, Sasaki S, Shimoda T, et al. Renal tubular dysfunction in children living in the Aral Sea region. Arch Dis Childhood. 2003;88(11):966-8. https://doi.org/10.1136/adc.88.11.966

12. Shamsiyev AM, Khusinova SA. The influence of environmenta factors on human health in Uzbekistan. In: The Socioeconomic Causes and Consequences of Desertification in Central Asia. Dordrecht: Springer; 2008. p. 249-52. https://doi. org/10.1007/978-1-4020-8544-4_11

13. Au WW, Ruchirawat M. Biomarkers in population studies: Environmental mutagenesis and risk forcancer. Rev Environ Heath. 2009;24(2):17-27.

PMid: 19658318

14. Garsed DW, Marshall OJ, Corbin VD, Hsu A, Di Stefano L, Schröder J, et al. The architecture and evolution of cancer neochromosomes. Cancer Cell. 2014;26(5):653-67. https://doi. org/10.1016/j.ccell.2014.09.010 PMid:25517748

15. Kurtcer MA, Gnetestskaya VA, Mitkin VV, Kalinovskaya II, Kutakova YU. The results of prenatal screening for chromosomal pathology in Moscow. Obstetr Gynecol. 2010;3:32-5.

16. Kumsta C, Chang JT, Schmalz J, Hansen M. Hormetic heat stress and HSF-1 induce autophagy to improve survival and proteostasis in C. Elegans. Nat Commun. 2017;8:1-12. https:// doi.org/10.1038/ncomms14337

PMid:28198373

17. KolotiyAD, Vorsanova SG, Yurov YI, Demidova IA, BereshevaAK Cytogenetic and molecular cytogenetic investigations in the diagnosis of mosaic forms of chromosomal abnormalities in children. Russ Bull Perinatol Pediatr. 2011;2:23-9. Available from: https://www.cyberleninka.ru/article/n/tsitogeneticheskie-imolekulyarno-tsitogeneticheskie-issledovaniya-v-diagnostikemozaichnyh-form-hromosomnyh-anomaliy-u-detey.

18. Sycheva LP, Ivanov SI, Kovalenko MA, Zhurkov VS, Belyaeva NN Antsiferov BM. The cytogenetic status of children living in the vicinity of a pulp-and-paper mill. Gig Sanit. 2010;1:7-10. PMid:20373705

19. Bequette F. The Sea's dwindling harvest. UNESCO Courier 1994;12:41-4. Available from: https://www.questia.com/ magazine/1G1-16476565/the-sea-s-dwindling-harvest.

20. Nazhmetdinova AS, Sarmanbetova GK. Risk assessment under the influence of persistent organic pollutants (pops) and heavy metals on the population of the Aral Sea region. Mod Probl Sci Educ. 2016;6:127-37.

21. Lioubimtseva E. A multi-scale assessment of human vulnerability to climate change in the Aral Sea basin. Environ Earth Sci. 2015;73(2):719-29. https://doi.org/10.1007/s12665-014-3104-1

22. Zhang W, Ma L, Abuduwaili J, Ge Y, Issanova G, Saparov G. Distribution characteristics and assessment of heavy metals in the surface water of the Syr Darya River, Kazakhstan. Polish J Environ Stud. 2019;29(1):979-88. https://doi.org/10.15244/ pjoes/104357

23. Sakiev KZ, Ibrayeva LK, Spirin VF, Otarbayeva MB, Grebeneva OV. Assessment of polluting factors of atmospheric air in arid areas in the warm season. Public Health and Life Environ. 2016;9(282):53-5.

24. Moorhead PS, Nowell PS, Mellman WJ, Battips DT, Hungerford DA. Chromosome preparation of leukocytes cultured from human peripheral blood. Exp Cell Res. 1960;20(3):613-6. https://doi.org/10.1016/0014-4827(60)90138-5

PMid:13772379 
25. Hungerford DA. Leukocytes cultured from small inocula of whole blood and the preparation of metaphase chromosomes by treatment with hypotonic KCl. Stain Technol. 1965;40(6):333-8. https://doi.org/10.3109/10520296509116440 PMid:5866557

26. Sabirov JB, Namazbayeva ZI, Ibraeva LK, Zhanbasinova NM The use of cytogenetic method of accounting for chromosomal aberrations for the study of mutagenicity in an unfavorable ecological situation. Occup Hyg Med Ecol. 2017;4(57):65-88.

27. Goloshchapov AP. Genetic and Biochemical Aspects of Human Adaptation to the Conditions of the City with Developed Chemical Industry. Moscow: Association of Scientific Publications KMK; 2012. Available from: https://www.books. google.kz/books?hl=ru\&lr\&id=dBdfDwAAQBAJ\&oi=fnd\&pg=P

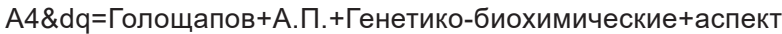
ы+адаптации+человека+к+условиям+города+с+развитой+ химической +промышленностью.+-+М.:+Товарищест\&ots= NraMFSBI0p\&sig=B10uv1eV_N_J5c1B2MiS7hLTOHI\&redir_ esc=y\&pli=1\&authuser=1\#v=onepage\&q=Голощап А.П. \% 20Генетико-биохимические $\% 20$ аспекты $\% 20$ адаптации \% 20 человека $\% 20$ к 20 условиям \% 20 города \% 20 с \% 20 развитой \% 20 химической \% 20 промышленностью.\%20-\% 20M. $\% 3 \mathrm{~A} \% 20$ Товарищест\&f=false.

28. Hoa NT, Trubnikova EV, Komkova GV, Zheleznova MA, Radionova MA, Shulgin I. Comparative analysis of the level of spontaneed mutagenesis in residents of Zheleznogorsky district in 2018. Int J Genomics. 2019;1(1):22-5. https://doi. org/10.32743/2658-6460.2019.1.1.40

29. Kharchenko TV, Arjavkina LG, Yazenok AV, Siniachkin DA, Zhekalov AN. Genotoxic alterations in the personnel of chemical stockpile disposal facilities. Toxicol Rev 2016;138(3):36-40.

30. Buckton KE, Evans HJ. Methods for the Analysis of Human Chromosome Aberrations. Geneva: World Health Organization; 1973.

31. World Health Organization. International Commission for Protection against Environmental Mutagens and Carcinogens. Guide to Short-term Tests for Detecting Mutagenic and Carcinogenic Chemicals. Geneva: World Health Organization; 1985. p. 101. Available fronm: https://www.apps.who.int/iris/ bitstream/ handle/10665/38607/9241541911-corr-eng.pdf? sequence $=1 \&$ isAllowed $=y$.

32. Sabirov ZB. Ways of occurrence of structural mutations in the chemical nature of mutagenesis. Occup Hyg Med Ecol 2015;2(47):26-31.

33. Diss G, Gagnon-Arsenault I, Dion-Coté AM, Vignaud $H$, Ascencio DI, Berger CM, et al. Gene duplication can impart fragility, not robustness, in the yeast protein interaction network. Science. 2017;355(6325):630-4. https://doi.org/10.1126/ science.aai7685

PMid:28183979

34. Sevan'kaev AV, Khvostunov IK, Lloyd DC, Voisen PH, Golub EV, Nadejina NM, et al. The suitability of FISH chromosome painting and ESR-spectroscopy of tooth enamel assays for retrospective dose reconstruction. J Radiat Res. 2006;47:A75-80. https://doi. org/10.1269/jrr.47.a75

35. Hagmar L, Bonassi S, Stromberg U, Brøgger A, Knudsen LE, Norppa $\mathrm{H}$, et al. Chromosomal aberrations in lymphocytes predict human cancer: A report from the European study group on cytogenetic biomarkers and health (ESCH). Cancer Res. 1998;58(18):4117-21. https://doi.org/10.1016/ s0027-5107(98)00134-1

PMid:9751622

36. Dalle-Donne I, Rossi R, Colombo R, Giustarini D, Milzani A. Biomarkers of oxidative damage in human disease. Clin Chem. 2006;52(4):601-23. https://doi.org/10.1373/ clinchem.2005.061408

PMid:16484333

37. Prodanchuk NG, Balan GM. The toxic effects of xenobiotics on stem cells as a risk factor for the development of general and oncological diseases. Mod Probl Toxicol 2010;1(48):17-41.

38. Puchkova AO, Kasyanenko NA. The investigation of DNA interaction with metal ions in presence of catechin, epicathechin and caffeine. Vestnik of Saint Petersburg university. Physics Chem. 2011;2:96-102.

39. Cortés-Eslava J, Gómez-Arroyo S, Risueño MC, Testillano PS. The effects of organophosphorus insecticides and heavy metals on DNA damage and programmed cell death in two plant models. Environ Pollut. 2018;240:77-86. https://doi. org/10.1016/j.envpol.2018.04.119

PMid:29729572

40. Nersesyan A, Kundi M, Mišík M, Wultsch G, Knasmueller S. Heavy metals-lead, mercury and cadmium and their impact on DNA damage measured by the micronucleus assay. In: The Micronucleus Assay in Toxicology. London: Royal Society of Chemistry; 2019. p. 435-49. https://doi. org/10.1039/9781788013604-00435

41. Morales ME, Derbes RS, Ade CM, Ortego JC, Stark J, Deininger PL, et al. Heavy metal exposure influences double strand break DNA repair outcomes. PLoS One. 2016;11(3):e0151367. https://doi.org/10.1371/journal. pone.0151367

PMid:26966913

42. Blagoi YP. DNA interaction with biologically active substances (metal ions, dyes, drugs). Soros Educ J. 1998;10(35):18-25.

43. Khlebodarova TM, Oshchepkov DY, Levitsky VG, Podkolodnaya OA, Ignatieva EV, Ananko EA, et al. Effect of flanking sequences on the accuracy of the recognition of transcription factor binding sites. Vavilov J Genet Breed. 2014;18(4/2):876-86. https://doi.org/10.1134/ s2079059715040073

44. Nemec AA, Wallace SS, Sweasy JB. Variant base excision repair proteins: Contributors to genomic instability. Semin Cancer Biol. 2010;20(5):320-8. https://doi.org/10.1016/j. semcancer.2010.10.010

PMid:20955798 